\title{
El enigma de Walter Benjamin
}

\author{
Javier Sigüenza
}

El siguiente ensayo inicia reconstruyendo el relato de los últimos días de la vida de Walter Benjamin, en el contexto histórico de la Segunda Guerra Mundial, y la existencia de un misterioso manuscrito perdido en su frustrada huida por la frontera franco-española en 1940; en la segunda parte se intenta descifrar la enigmática fisionomía del pensador berlinés, cuya perspectiva múltiple, tanto en lo teórico como en lo político, lo convierten en un autor incomprendido, pero tremendamente fascinante; en la tercera parte se explora uno de sus textos más herméticos, conocido como las tesis Sobre el concepto de historia, con la intención de poner de manifiesto el carácter crítico de su discurso, como clave para comprender los enigmas del mundo moderno y su necesaria transformación revolucionaria.

Palabras ClaVe: Walter Benjamin, memoria, historia, mesianismo, marxismo.

The following essay begins by reconstructing the story of the last days in the life of Walter Benjamin, in the historical context of World War II and the existence of a mysterious manuscript lost in his abortive escape across the FrancoSpanish border in 1940. In the second part, we try to decipher the enigmatic physiognomy of the Berlin thinker, whose multiple perspectives, both theoretically and politically, render him a misunderstood but endlessly fascinating author. In part three we explore one of Benjamin's most hermetic texts, his Theses on the Philosophy of History, with the intention of highlighting the critical nature of his speech as key to understanding the mysteries of the modern world and its necessary revolutionary transformation.

KEYwords: Walter Benjamin, memory, history, messianism, marxism. 
Fecha de recepción: 9 de octubre de 2013

Fecha de aceptación: 2 de diciembre de 2013 
Javier Sigüenza

Universidad Nacional Autónoma de México

Facultad de Filosofia y Letras

\section{El enigma de Walter Benjamin}

\section{In Memoriam Bolívar Echeverría}

Das destruktive oder kritische Element in der Geschichtesschreibung kommt in der Aufsprengung der historischen Kontinuität zur Geltung.

Walter Benjamin. Über den Begriff der Geschichte.

En su libro Mi travesía de los Pirineos, Lisa Fittko narra la inesperada visita que recibió un día de septiembre de 1940, cuando se hallaba en una estrecha y pequeña buhardilla en Port-Vendres, al sur de Francia:

Hacía un par de horas que me había acostado cuando me despertaron unas llamadas a la puerta... me levanté y, soñolienta, abrí la puerta. Me froté los ojos asombrada, ante mis ojos se encontraba uno de nuestros amigos, Walter Benjamin, quien, como tantos otros, se había refugiado en Marsella cuando los alemanes habían invadido Francia (133).

Durante más de quince años, Walter Benjamin se había negado a abandonar Europa, pues expresó en varias ocasiones que aún había posiciones que defender allí. A mediados de 1940, sin embargo, le re- 
sultó imposible permanecer más tiempo en París. Con la ocupación de Francia por el régimen nazi la situación se volvió totalmente insegura para él, al igual que para muchos refugiados: se sabía que judíos, y en general gente de izquierda, eran sacados durante la noche de sus casas y llevados a paraderos desconocidos. Benjamin tenía aún la esperanza de que ante el avance del fascismo en Europa, el proletariado lograra unificarse, parar la guerra y hacer la revolución. Como es sabido, la revolución no llegó, pero sí "la época de la guerra total".

1940 fue un año funesto, en el que Alemania derrotó a Noruega, Dinamarca, Países Bajos, Bélgica e invadió Francia. Los primeros cuatro países fueron ocupados y Francia dividida en dos. Esto no era, sin embargo, un estado de excepción sino la regla, como afirmaría el mismo Benjamin. La consecuencia más extrema de una situación que venía generándose desde hacía ya varios años atrás, con una serie de hechos que fueron el preludio del drama macabro que los fascistas montaron en el escenario mundial: la invasión de Etiopía por Italia en 1935; la intervención de los alemanes e italianos en la Revolución española en 1936; la anexión de Austria por parte de Alemania, la invasión de los nazis de Checoslovaquía en 1939, o la ocupación de Albania por Alemania, ese mismo año. Hechos que además pusieron en evidencia el dócil sometimiento de las democracias occidentales y del socialismo realmente existente a los designios del Tercer Reich; el tratado de München de 1938 permitió de facto a Alemania ocupar territorios de Checoslovaquía, y el tratado de no agresión entre el régimen soviético y los nazis permitió a ésta ocupar territorios polacos. ${ }^{2}$

En medio de esta catastrófica situación estaba Benjamin, intentando aún defender posiciones contra el fascismo y a favor de la revolución, con las únicas armas que poseía y que sabía manejar con una maestría sin igual: la fuerza del pensamiento crítico, su enigmática escritura y su cortesía casi chinesca.

Estimada señora le ruego que perdone la molestia, espero no haber llegado en momento inoportuno. - Pensé: el mundo está saliéndose de

${ }^{1}$ Término usado por Eric Hobsbawm en su libro Historia del siglo XX.

${ }^{2}$ Cfr. Eric Hobsbawm, Historia del siglo XX, 148-181. 
quicio, pero la cortesía de Benjamin permanece inalterable- . Su señor esposo me ha explicado cómo podía encontrarla. Me dijo que usted me llevaría a España, cruzando la Frontera (Fittko, Mi travesía de los Pirineos, 133-134).

Lisa Fittko era una judía-vienesa antifascista, que fue parte de la resistencia silenciosa que luchó contra el nazismo y ayudó durante varios años a los que huían de los nazis a cruzar la frontera. En aquellos meses, los caminos de huida se habían vuelto inseguros; los gardes mobiles, por ordenes de la delegación de la Gestapo en Francia, mantenían una estrecha vigilancia. Pero la señora Fittko había encontrado una nueva ruta, gracias a la ayuda de los trabajadores de la región y al alcalde de Banyuls-sur-mer: el señor Azéma. Se trataba de un viejo sendero de contrabandistas que fue conocido como la route Lister; el camino, sin embargo, implicaba varios riesgos desconocidos: la señora Fittko sólo contaba con un croquis que le había hecho el señor Azéma, y el sendero llevaba hacia la parte más alta de la montaña, por lo que la subida sería muy trabajosa, en especial para Benjamin, que padecía trastornos cardíacos: “¿Quiere correr estos riesgos? — preguntó la señora Fittko a Benjamin-, Claro que sí dijo..., sin el menor titubeo. El auténtico riesgo sería no ir" (136). Con Benjamin habían venido desde Marsella la señora Gurland y su hijo José. Para conocer el camino que iban a recorrer, hicieron un paseo de exploración con la señora Fittko fingiendo ser turistas. Benjamin llevaba una maleta que le llamó la atención a la señora Fittko:

—Ahí dentro va mi nuevo manuscrito — me aclaró. — ¿Pero por qué se ha traído consigo esa maleta... si sólo vamos a explorar el terreno. - Mire, esta cartera es para mí lo más importante de todo. De ninguna manera puedo perderla. Es necesario que ese manuscrito se salve. Es más importante que yo mismo (137). ${ }^{3}$

Luego de andar un par de horas, llegaron a un lugar despejado al lado de un gigantesco risco, descansaron un momento y después se dispusieron a iniciar el descenso, pero Benjamin se negó a regresar, a pesar de la insistencia de las señoras Fittko y Gurland, pues ya había recorrido

${ }^{3}$ Las cursivas son mías. 
una tercera parte del camino y el objetivo que perseguía era cruzar la frontera y no permitir que su manuscrito cayera en manos de la Gestapo, si regresaba y al día siguiente hiciera otra vez todo el trayecto, quizá su corazón no resistiría, por lo tanto, concluyó, se quedaría ahí (138). Las dos señoras intentaron persuadirlo de que volvieran juntos, pues permanecer allí sería peligroso, pero la determinación de Benjamin era inamovible, así que las dos señoras y el joven regresaron sin él al poblado. Benjamin pasó esa noche a la intemperie, sumergido seguramente en sus reflexiones, preocupado por poner a salvo su texto, como si de ello dependiera el curso de la historia misma.

Al día siguiente de nueva cuenta salieron muy temprano, antes de que amaneciera, para mezclarse entre la gente que iba al campo y así evitar ser detenidos. Iban bastante preocupados por Benjamin, y cuando al fin lograron llegar al lugar en donde había permanecido el día anterior, afortunadamente lo encontraron a salvo. Emprendieron la marcha entre "caminos lisos de roca y bajo un intenso calor" (138), subiendo por las vides: "Allí, en aquella viña, fue donde Benjamin flaqueó por primera y única vez... y declaró, con palabras serenas, que aquello estaba por encima de sus fuerzas" (138). La señora Fittko y el joven José lo tomaron por los brazos y le ayudaron a subir la cuesta: "Benjamin respiraba con dificultad, pero no se quejó... Sin embargo, una y otra vez echaba miradas a su cartera" (138).

Cuando por fin llegaron a la cumbre, pasaron al lado de un charco de agua hedionda y verdosa, frente al que Benjamin se arrodilló para beber. Lisa Fittko le dijo que no debería hacerlo, porque el agua sin duda estaba contaminada y corría el riego de adquirir tifus, a lo que Benjamin repondió: "Discúlpeme pero no me queda otro remedio. Si no bebo de este charco, tal vez no logre llegar hasta el final. Lo peor que puede pasar es que muera de tifus... después de haber cruzado la frontera. La Gestapo no podrá ya detenerme y el manuscrito estará a salvo (143145; las cursivas son mías). Benjamin bebió del agua, pudo continuar el ascenso; después de casi diez horas por fin llegaron a la cumbre desde donde se veía el poblado de Port-Bou, en la frontera con España, allí la señora Fittko dejó al grupo para que continuara su camino.

Años más tarde, la señora Gurland contó que una vez en Port-Bou se enteraron de que se había promulgado un decreto que establecía que no 
se permitiría el paso por territorio español a gente sans nationalité. Por más que rogaron, lloraron y mostraron los documentos en regla a los oficiales fronterizos, no les permitieron pasar. Además, Benjamin y el joven José sólo tenían un documento del gobierno estadounidense, por lo que muy probablemente serían entregados a la Gestapo y llevados a un campo de concentración. Todos se fueron desesperanzados a un hotel de Port-Bou, para pasar la noche bajo vigilancia. A las siete de la mañana Benjamin llamó a la señora Gurland a su habitación, le dijo que había injerido una fuerte cantidad de morfina, que debía de hacer parecer que estaba enfermo, le dio una carta para Theodor W. Adorno y luego se desmayó. La señora Gurland fue presa de los peores temores, hasta que al día siguiente, por fortuna, un médico expidió el certificado de defunción y no hubo problemas con la policía. Dejó los papeles y las cosas de Benjamin con el juez y le pidió que lo mandara al Consulado norteamericano en Barcelona (262-263).

Benjamin murió el 27 de septiembre de 1940. Parece como si en su intento por huir hubiera pensado en todas las posibilidades, incluido el suicidio, pues llevaba preparada suficiente morfina para quitar varias vidas (Wohlfarth, Hombres del extranjero..., 141). Como una última burla del destino, al día siguiente las autoridades españolas permitieron el paso al grupo. Según Hannah Arendt esta situación era para cualquier otra persona un "golpe de mala suerte" inusual, pero no para Benjamin, quien con frecuencia tenía que enfrentarse a las peores dificultades: "Un día antes y Benjamin hubiese pasado sin ningún problema; un día después y la gente de Marsella habría sabido que en ese momento era imposible pasar a través de España. Sólo en ese día en particular era posible la catástrofe" (Arendt, Hombres en tiempos..., 152). Pero la catástrofe no sólo alcanzó a Benjamin, sino a millones de víctimas del fascismo y el nacionalsocialismo, una vez más, esta situación no era una excepción sino la regla.

El manuscrito que tanto protegía Benjamin parece haberse perdido para siempre. Su amigo de toda la vida, Gerschom Scholem, considera la posibilidad de que haya sido un avance significativo de La obra de los pasajes (Das Passagen-Werk), su obra cumbre, que jamás llegó a concluir. Aunque según los informes de la policía fronteriza española, que obtiene Max Horkheimer años más tarde, no había ningún manuscrito 
grueso dentro de la maleta que afirme la suposición de Scholem, aunque es probable que con la caligrafía diminuta de Benjamin no necesitara grandes folios para transportarla. Por su parte, Rolf Tiedemann considera que en realidad el manuscrito era otro texto, quizás el último que Benjamin redactó antes de su muerte, conocido como las tesis Sobre el concepto de historia (Über den Begriff der Geschichte). ${ }^{4}$ Hasta el día de hoy sigue siendo un misterio de qué manuscrito realmente se trataba, un enigma más que rodea la vida y obra de Walter Benjamin.

Con la publicación póstuma de la obra de Walter Benjamin no se resolvió el misterio del manuscrito perdido y, por el contrario, como afirma Rolf Tiedemann, se abrieron nuevos enigmas en torno a su fisonomía intelectual. ${ }^{5}$ Si consideramos la obra escrita como algo vivo, escribió Benjamin, la vida de la obra es aquello que se conforma durante la vida del autor, cuando el autor muere, la obra entra en una etapa de supervivencia (Überleben), si los contenidos objetivos y de verdad cifrados en la obra resultan significativos, entonces la traducción, el comentario y la crítica le otorgarán a la obra una pervivencia (Fortleben) duradera, en ellas la obra alcanza su expansión póstuma más vasta y siempre renovada. ${ }^{6}$

Significativa resulta sin duda la obra del mismo Benjamin, que con su trágica muerte entró en un largo periodo de hibernación, la recepción de su legado realmente no inició sino hasta la vuelta de los miembros del Instituto de Investigaciones Sociales de Frankfurt a Alemania, después de la Segunda Guerra Mundial. La fama póstuma, escribió Hannah Arendt, es quizá la más ingrata y al mismo tiempo la menos deseada de todas las formas de la fama, aunque también la más segura y duradera. ${ }^{7}$

${ }^{4}$ Cfr. Walter Benjamin, Über den Begriff Der Geschichte.

${ }^{5}$ Cfr. Rolf Tiedemann en: Walter Benjamin, Das Passagen-Werk. Gesammelte Schriften, t. v, vol. 1.

${ }^{6}$ Cfr. Walter Benjamin, "Die Aufgabe des Übersetzers", en Gesammelte Schriften, t. IV, vol. 1. Versión castellana: "La tarea del traductor", en Conceptos de filosofía de la historia.

${ }^{7}$ Cfr. Arendt, Hombres en tiempos... 
Casi treinta años después de su muerte, en los años setenta, esa fama póstuma recayó en Alemania sobre el nombre de Walter Benjamin, y poco a poco se fue extendiendo a otros países de Europa, como Francia e Italia, y del otro lado del Atlántico en América Latina y Estados Unidos de Norteamérica, y hasta el día de hoy su obra sigue siendo objeto de agitados y apasionados debates, especialmente en el contexto latinoamericano.

El interés por la obra de este pensador iconoclasta se debe a su enorme apertura intelectual, en la que se ponen en juego el discurso filosófico y la crítica de arte, la sociología y la crítica literaria, la teología y el materialismo histórico, el marxismo y el anarquismo, pero no con la intención de llegar a una síntesis superior, sino como un esfuerzo intelectual para aproximarse a la diversidad de lo real, sin reducirla a alguna disciplina académica o a una concepción ideológica en particular. Desde una perspectiva filosófica es posible ubicar el pensamiento de Benjamin en la encrucijada de la historia de los fenómenos culturales y de la crítica de la economía política, pero a diferencia del marxismo economicista, Benjamin no pretendió reducir los fenómenos culturales a los hechos económico-políticos, sino más bien intentó penetrar de forma crítica en los hechos histórico-sociales a partir de los fenómenos culturales.

Por otra parte, la posición política de Benjamin sin duda lo vincula con la izquierda revolucionaria, pero no con el Partido Comunista, al que estuvo en algún momento tentado a incorporarse, pero al que nunca se afilió debido a sus constantes desencuentros con la política del partido; menos aún con la socialdemocracia, a la que criticó férreamente desde su juventud hasta sus últimos escritos y, si bien estuvo muy cercano a las posiciones libertarias, tampoco se le puede considerar propiamente un anarquista. En realidad, Benjamin perteneció a una izquierda intelectual de nuevo cuño, desde la que se cuestionaron los presupuestos teóricos que guiaban la práctica política de la izquierda comunista, del marxismo vulgar, como también lo llamó y que renovó el carácter crítico del discurso de Marx, desde una posición libertaria, ${ }^{8}$ asumida

${ }^{8}$ El término libertario se refiere a los anarquistas, que como el mismo Benjamin afirma: "Seit Bakunin hat es in Europa keinen radikalen Begriff von Freiheit mehr gegeben. Die Sürrealisten haben ihn" (Desde Bakunin no hay un concepto de libertad en Europa tan radical como el que los surrealistas tienen). Cfr. Walter Benjamin, "Der Sü- 
tanto por anarquistas como por algunos miembros de las vanguardias artísticas de principios del siglo $\mathrm{xx}$.

Para un pensamiento habituado a la férrea disciplina de las ciencias, estos rasgos de la fisonomía intelectual de Benjamin lo convierten en un pensador inclasificable. Un pensador que se opuso al pretencioso gesto del tratado y buscó formas más adecuadas de expresión en el seno de las comunidades activas. De allí su especial predilección por la forma ensayística de la escritura, las imágenes reflexivas (Denkbilder) y dialécticas (dialektische Bilder), los aforismos y las tesis. Formas que son para el aparato de la vida social, escribe en Einbahnstraße (Calle de dirección única), lo que el aceite a las máquinas. Nadie se pone frente a una máquina y la inunda de aceite, sino que pone un poco de lubricante en roblones y junturas que es necesario conocer. ${ }^{9}$ Aunque tardíamente, el pensamiento crítico de Benjamin ha tenido ese efecto de lubricante sobre la vieja maquinaria del discurso, que corre el riesgo siempre de caer en manos del conformismo.

\section{III}

Uno de los textos de Walter Benjamin que ha despertado particular interés en las últimas décadas, a pesar de su carácter hermético es el de las tesis Sobre el concepto de historia, cuya última versión quizá sea, como se mencionó antes, el manuscrito que Benjamin tanto protegía en su frustrada huida. Tal interés no deja de resultar paradójico, ya que Benjamin no tenía la intención de publicarlas, porque no las consideraba algo definitivo, sino una colección de ideas provisionales recolectadas en paseos reflexivos y no deseaba que su publicación abriera las puertas a la incomprensión entusiasta. ${ }^{10}$

rrealismus. Die letzte Momentaufnahme der europäischen Intelligenz", en Gesammelte Schriften, t. II, vol. 1, 306. (La traducción es mía).

${ }^{9}$ Walter Benjamin. "Einbahnstraße", en Gesammelte Schriften t. IV, vol. 1, 85. Versión castellana: Walter Benjamin, Dirección única.

${ }^{10}$ En momentos diferentes, Benjamin escribe a sus amigos Gretel Adorno, Max Horkheimer, Theodor W. Adorno y Gerschom Scholem, las consideraciones anteriores. Cfr. Walter Benjamin, Gesammelte Schriften, t. I, vol. 3, 1223-1229. 
Sin embargo, los objetivos que perseguía al escribirlas no eran menores, se trataba de una serie de consideraciones metodológicas, surgidas como paralipómenos de sus trabajos sobre La obra de los pasajes, una especie de reflexión teórica del conocimiento, de las que ya se había ocupado en su ensayo sobre Eduard Fuchs, y que servirían de armazón teórica para sus ensayos sobre la poética de Baudelaire. Además, pretendía con ellas liberar al "materialismo histórico" de ciertos resabios positivistas, particularmente del concepto de progreso, que persistían en él; y ocuparse de nociones fundamentales, como memoria y olvido, para una concepción crítica de la historia. Escribe también que estas reflexiones las había albergado durante al menos veinte años y adquirieron una especial importancia en la constelación histórica de la guerra. ${ }^{11}$ Aunque, como bien señala Michael Löwy, las tesis van más allá del contexto histórico inmediato de su redacción ya que platean cuestiones que se refieren de manera crítica a la concepción de la historia moderna en su conjunto. ${ }^{12}$ De allí el enorme interés que han despertado en otros contextos histórico-culturales, como el latinoamericano, en el que además de las discusiones sobre los contenidos de las tesis, algunas de sus ideas han sido actualizadas para pensar críticamente los procesos históricos fuera de Occidente.

Las tesis fueron publicadas por vez primera en 1942 por Adorno, en un número especial de la Revista del Instituto de Investigaciones Sociales de Frankfurt, titulado Walter Benjamin zum Gedächtnis (En homenaje a Walter Benjamin), en Los Ángeles, cuando el Instituto aún se encontraba en el exilio en Estados Unidos; cinco años más tarde, en 1947, Pierre Missac las tradujo al francés y las publicó en la famosa revista Les temps modernes; y en 1950, Adorno volvió a publicarlas en la revista Neue Rundschau. Estas primeras publicaciones no suscitaron demasiado interés en el mundo intelectual europeo de aquellos años, más que en sus editores, que ya se habían percatado de la importancia de la crítica que contenían. No fue sino hasta la publicación de una selección de ensayos de Benjamin en 1955, entre los que se encontraban

${ }^{11}$ Cfr. Walter Benjamin. Gesammelte Schriften. t. I, vol. 3, 1223-1229.

${ }^{12} \mathrm{Cfr}$. Michael Löwy, Walter Benjamin: aviso de incendio: una lectura de las tesis "sobre el concepto de la historia". 
las tesis, en un par de libros que llevaron por título Schriften, y más tarde, en 1961, otro llamado Iluminationen y en 1966, Angelus Novus, cuando empezó la discusión sobre el pensamiento de Benjamin en un pequeño círculo de intelectuales en Alemania. A finales de los sesenta, y sobre todo en los setenta y ochenta, la fama póstuma finalmente tomaría el nombre de Walter Benjamin y su obra empezaría a adquirir una pervivencia duradera hasta la actualidad.

Desde entonces, las lecturas de los escritos de Benjamin se han debatido entre los extremos de la izquierda: marxistas y materialistas, el romanticismo y la hermenéutica de orientación filológica y una tradición teológica y judaica. ${ }^{13}$ Este debate tuvo una gran resonancia en otros países de Europa y también llegó a América Latina, en donde se han dado innumerables, y a veces divergentes, lecturas de sus escritos, y en particular de las tesis Sobre el concepto de historia. ${ }^{14}$ Resulta irónico que un autor que fue casi un desconocido en su tiempo, sea en la actualidad objeto de apasionados y polémicos debates en diversas partes del mundo.

Michael Löwy distingue al menos tres grandes tendencias interpretativas de las tesis, por una parte, la concepción materialista, para la que Benjamin es un marxista, cuyas consideraciones teológicas no son sino metáforas, que nos remiten a verdades materialistas (Bertolt Brecht); por otra parte, estaría la posición que defiende que, ante todo, Benjamin era un teólogo judío, que con frecuencia abusa de la terminología marxista, pero que en el fondo es un pensador mesiánico (Gerschom Scholem); finalmente, la posición que considera que Benjamin intentó conciliar marxismo y teología judía, materialismo y mesianismo, que debido a la incompatibilidad de estos discursos, llevaron al fracaso su tentativa (Jürgen Habermas y Rolf Tiedemann). ${ }^{15}$

Löwy, en su libro Walter Benjamin. Aviso de incendio, propone un cuarto enfoque, en el que Benjamin sería marxista y teólogo al mismo tiempo. Si bien marxismo y teología son concepciones incompatibles,

${ }^{13} \mathrm{Cfr}$. Horst Nitschack. "Walter Benjamin in Lateinamerika. Eine widersprüchliche Erfolgsgeschichte", en Wechselseitige Perzeptionen: Deutschland-Lateinamerika im 20.

${ }^{14}$ A la lengua castellana, las tesis se han traducido al menos en siete diversas ocasiones, desde 1967 hasta la actualidad.

${ }^{15}$ Cfr. Löwy, Walter Benjamin..., 42. 
Löwy sugiere que Benjamin las reinterpreta, las transforma, las "sitúa en una relación de esclarecimiento recíproco que permite articularlas de manera coherente" (41-42). De allí que se viera a sí mismo como un Jano, que mira hacia Moscú con un rostro y con el otro mira hacia Jerusalén. Dos rostros, pero una sola cabeza, afirma: "marxismo y mesianismo no son sino las dos expresiones [...] de un sólo pensamiento" (42), una paradójica reversibilidad reciproca, del marxismo en el mesianismo y viceversa. Tal relación entre revolución y redención es establecida por Löwy a partir de la noción de afinidad electiva (Wahlverwandtschaften), es decir, una "atracción mutua y fortalecimiento recíproco de las dos actitudes, a partir de ciertas analogías estructurales que conducen a una especie de fusión alquímica" (42).

La idea de Löwy resulta muy atractiva, sobre todo por el especial cuidado con el que reflexiona sobre el concepto de Wahlverwandtschaft (afinidad electiva), ${ }^{16}$ para intentar comprender la tentativa discursiva de Benjamin. Sin embargo, quizá el enigma que nos plantean las tesis en su conjunto sea posible descifrarlo más a partir de sus contenidos críticos, que de sus posibles tentativas programáticas, es decir, que el momento central de las tesis es la crítica, que Benjamin cultiva a partir de la yuxtaposición de diversos discursos, como el del materialismo histórico, el de la teología, el mesianismo y el utopismo; pero no para afirmar ortodoxamente alguno de ellos, tampoco para conjuntarlos en una síntesis superior, o fusionarlos de manera electiva, sino para poner en crisis el discurso moderno, racionalista, positivista, cientificista de la historia, en el que el "materialismo histórico" de su tiempo también permanecía atrapado.

Desde esta perspectiva, una aproximación a las tesis nos permite ubicar tres temáticas principales. La primera: una crítica de los resabios positivistas que prevalecen en el "materialismo histórico", particularmente a la idea de historia y de tiempo que le es inherente, y sobre todo al concepto de progreso; segunda: una crítica a las concepciones de la política y del trabajo del marxismo vulgar, es decir, de la socialdemocracia y del marxismo bolchevique; tercera, una renovación del mismo

\footnotetext{
${ }^{16}$ Cfr. Michael Löwy, Redención y utopía: el judaísmo libertario en Europa central: un estudio de afinidad electiva.
} 
materialismo histórico, a partir de la introducción de algunas ideas del mesianismo judío, como memoria y tiempo mesiánico, y del utopismo, en especial su particular concepción de la naturaleza. ${ }^{17}$

Respecto al primer tema, se trata de un cuestionamiento a la visión de la historia que ha entrado en empatía (Einfühlung) con la visión de los vencedores, cuya concepción de la temporalidad es homogénea y vacía, y afirma dogmáticamente la idea de progreso, pues sólo ve los progresos técnicos-científicos, pero no reconoce los retrocesos sociales. Estas ideas han sido el fundamento teórico de una práctica política equivoca de la izquierda; de allí la necesidad de cuestionar las concepciones de la política y del trabajo, segundo tema, que afirma ingenuamente tanto la socialdemocracia como al marxismo del Partido Comunista. Según esa visión el escenario de lo político sería el Estado, sus instituciones, los partidos políticos, de allí que la lucha revolucionaria se encaminara por el control del aparato estatal, en vez de fomentar una verdadera construcción de lo político, es decir, la posibilidad de una participación directa de todos los individuos que componen la comunidad en la construcción de su sociabilidad y, por tanto, en la conformación de su libertad.

En otro sentido, Benjamin veía en la idea de trabajo del "marxismo vulgar" la resurrección de la antigua moral protestante, es decir, la autorepresión sublimada encaminada a la productividad y el sacrificio, que al igual que el capitalismo desposeían al trabajador del producto de su labor; estas concepciones además no solo fueron aquiescentes con el "espíritu del capitalismo", sino favorables al surgimiento del fascismo y del nacionalsocialismo. Finalmente, un tercer tema sería la necesaria renovación del materialismo histórico, que asuma que lo fundamental en la construcción de su discurso es el momento crítico, de allí que su labor sea el de cepillar a contrapelo la suntuosidad de la historia; tal renovación para Benjamin era posible si se introducían algunas ideas del mesianismo, por una parte, como la de memoria (Erinnerung), que sirve para recuperar la memoria de los vencidos que lucharon por su liberación y que fueron derrotados; la idea de tiempo mesiánico, es decir, un tiempo actual (Jetztzeit), en el que la lucha por la libertad, la felici-

${ }^{17}$ Bolívar Echeverría, Valor de uso y utopía, 53. 
dad y la abundancia no sean postergados a un futuro inalcanzable, sino que deben realizarse en el aquí y en el ahora. Por otra parte, lo utópico -que para Benjamin resulta pertinente para cuestionar la visión antropocentrista moderna y su concepción meramente instrumental de la naturaleza-, para lo cual propone una concepción, según la cual lejos de explotar a la naturaleza, le ayude a parir las creaciones que dormitan en su seno. Ideas que para Benjamin resultan más eficaces en la lucha contra el fascismo y favorables a la revolución social.

Por lo tanto, la tentativa benjaminiana consiste más que en una fusión de motivos dispares, o la afirmación dogmática de alguno de ellos, ya sea el marxismo o el mesianismo, en una puesta en juego, una puesta en tensión del discurso filosófico, del materialismo histórico y del mesianismo judío, para la renovación del carácter crítico del discurso revolucionario. En este sentido, podemos afirmar con Bolívar Echeverría que la actualidad del discurso benjaminiano consiste en ofrecernos "innumerables claves para descifrar el mundo moderno, vías de acceso difíciles pero iluminadoras a los secretos que le vuelven enigmático" (Valor de uso y utopía, 53); se podría agregar, un desciframiento crítico del mundo moderno para su deseable y necesaria transformación.

Del conjunto de las tesis, una de las más inquietantes, enigmáticas y discutidas es la tesis I. En ella, Benjamin evoca una imagen del pasado, según la cual hubo un autómata jugador de ajedrez que era capaz de responder al movimiento de cualquier contrincante y ganarle la partida. En realidad, bajo la mesa del autómata había un enano jorobado que controlaba al muñeco. Conforme el lector avanza en la lectura de esta tesis, la oscuridad va en aumento, porque Benjamin establece un equivalente de ese mecanismo en el ámbito de la filosofía, en el que el muñeco que siempre gana es el "materialismo histórico" y el enano jorobado sería la teología. ${ }^{18}$

${ }^{18}$ Cfr. Benjamin, Über den Begriff Der Geschichte, 9. 
Para intentar descifrar esta enigmática tesis es necesario tener en cuenta que las imágenes en el pensamiento de Benjamin expresan algo más que un estilo literario. Cuando Benjamin se aproxima al pasado descubre en él imágenes históricas petrificadas, que en su época se habían arraigado en el imaginario social como sueños de la modernidad, y que en el transcurso histórico se habían revelado como mera ilusión, sin embargo, resurgen constantemente bajo formas inesperadas y reifícadas, de allí la necesidad de la crítica de esas imágenes; para ello, Benjamin acuñó el concepto de imagen dialéctica (dialektisches Bild), inspirado en el uso alegórico de los dramaturgos barrocos y la poética alegórica de Baudelaire.

Resulta conveniente también recordar que las tesis eran una serie de consideraciones crítico-epistemológicas que se relacionaban estrechamente con la Obra de los pasajes, misma que, como se sabe, Benjamin no logró concluir debido a la persecución de la que fue objeto y lo llevó al suicidio. El proyecto de los pasajes tenía como objetivo, entre otras cosas, construir una historia crítica de la modernidad, desde la perspectiva de la vida cotidiana: los pasajes, las galerías y bulevares, así como las figuras prototípicas de la época: el poeta, el ropavejero (Chiffonnier), el conspirador y el que deambula (flâneur). Este proyecto constituía un esfuerzo teórico por comprender en forma crítica el origen de la modernidad a partir de ciertas imágenes del pasado: una filosofía de la historia de los pasajes, en la que Baudelaire aparece como el genio alegórico, que transfigura París en objeto de la poesía lírica. Las figuras centrales del proyecto eran el flâneur, que sólo puede encontrar asilo entre la multitud, en una ciudad que aparece como fantasmagoría, y el chiffonnier, que al alba de la revolución aparece como el coleccionista de imágenes dialécticas. ${ }^{19}$ Desde esta perspectiva, la ciudad se convierte en el reservorio de las imágenes dialécticas, que es posible descifrar en los pasajes, imágenes mediante las que cada generación sueña a la siguiente y perpetúan la experiencia colectiva de una época. ${ }^{20}$

${ }^{19}$ Jean Michel Palmier, Walter Benjamin: le chiffonnier, l'ange et le petit bossu: esthétique et politique chez Walter Benjamin, 782-783.

${ }^{20}$ En sus estudio sobre el surrealismo comenta con acierto Michel Palmier: Benjamin encontró el vinculo entre la imagen, el sueño y la modernidad; para él, los escritos 
Theodor W. Adorno criticó fuertemente los conceptos de imagen dialéctica y fantasmagoría de Benjamin en tres aspectos; primero, consideraba que Benjamin hacía del fetichismo de la mercancía, que aparece en el culto de Baudealaire a la novedad, un fenómeno meramente de conciencia, cuando se trata de un fenómeno social; segundo: considera además que el ensayo era más una acumulación de materiales, que una teoría, más un modelo de los pasajes que una introducción a la obra, y por último, que haya hecho un simple ensamble de temas y materiales sin mediación dialéctica alguna, forzando sus intuiciones personales en un esquema marxista muy ortodoxo. ${ }^{21}$ Benjamin reconoce que algunas de las observaciones críticas de Adorno están bien fundadas, pero sigue defiendo su método basado en las imágenes dialécticas. ${ }^{22}$

Sobre este tema, Jean Michel Palmier señala que en realidad esta discusión ponía de manifiesto no solo la diferencia de método entre Benjamin y Adorno, sino de sensibilidad. Señala también que los ensayos sobre Baudelaire y el proyecto de los Pasajes están unidos estrechamente por la mitología de la modernidad del segundo imperio y por una constelación conceptual que se articula en torno al concepto de imagen dialéctica (dialektisches Bild) y dialéctica en detención (Dialektik im Stillstand); y que su teoría del conocimiento es inseparable de las nociones de imagen, sueño y despertar, como condiciones de posibilidad de la experiencia histórica. ${ }^{23}$

En efecto, el punto crucial de la crítica de Adorno, cuestionaba que Benjamin transponía un producto social colectivo a la conciencia, como una imagen y como un sueño. Pero de acuerdo con Jean Michel Palmier, Benjamin jamás pretendió que el fetichismo de la mercancía no fuera algo real, sino que él quería descifrarlo a partir de la fantasmagoría que lo suscita, que en sí misma es una reducción del universo. Lejos de querer subsumir el detalle a la teoría dialéctica, él quería cristalizarla

de Breton y Aragon transformaron la ciudad en enigma e hicieron surgir las energías revolucionarias de lo antiguo.

${ }^{21}$ Cfr. "Carta de Adorno a Benjamin: 2/agosto/1935", en Theodor Adorno y Walter Benjamin, Correspondencia: 1928-1940.

${ }^{22}$ Cfr. "Carta de Benjamin a Adorno: 9/diciembre/1938", en Theodor Adorno y Walter Benjamin, Correspondencia: 1928-1940.

${ }^{23}$ Cfr. Palmier, Walter Benjamin: le chiffonnier..., 785-786. 
en una constelación, en imágenes, en la que la sociedad se revele completamente. Esta capacidad de transformar los desechos de la historia en enigmas para descifrar el universo social a partir de sus imágenes es la extraña y poderosa propuesta de Benjamin con la que intenta desmitificar la modernidad y provocar el despertar del sueño colectivo. ${ }^{24}$ En este sentido, la alusión de Benjamin a imágenes del pasado y la construcción de imágenes dialécticas en su obra suponen un modo de concebir y pensar en forma crítica el mundo histórico social. Desde esta perspectiva, la imagen del autómata jugador de ajedrez adquiere una significación histórica más profunda, en la que se condensan de manera extraordinaria los contenidos de las tesis en su conjunto.

La imagen antes citada se refiere sin duda al autómata jugador de ajedrez construido por Wolfgang von Kempelen en 1769, para entretener a la emperatriz María Teresa, en el Palacio de Schönbrun en Viena. Durante varios años, el autómata se presentó además en diversas ciudades de Europa, como Presburg, Viena, París, Londres. Después de la muerte de von Kempelen, en 1804, el autómata fue adquirido por Johann Mäzel quien lo llevó a Estados Unidos, en donde después de varias presentaciones viajó a Cuba para realizar una gira por Hispanoamerica, pero al morir su ayudante procuró regresar a Estados Unidos, pero murió durante el viaje. El autómata terminó en el Museo Chino de Filadelfia y en un incendio en 1954 fue consumido por las llamas. ${ }^{25}$

También conocido como el Turco, o El hombre que siempre gana, el autómata perteneció a una época dorada de autómatas, entre los que destacan los de Jacques de Vaucanson, que construyó un flautista capaz de tocar varias melodías con gran maestría y un pato que graznaba, chapoteaba, bebía, comía y defecaba en una charola de plata; de él Voltaire expresó con ironía que si no fuera por el pato cagón nadie recordaría la gloria de Francia; otros autómatas más delicados y cautivadores fueron los de Pierre Jacques-Droz y su hijo Henri Louis, entre los que figuraba el Schreiber, que con un gesto reflexivo escribía irónicamente: cogito ergo sum. ${ }^{26}$

${ }^{24}$ Cfr. Palmier, Walter Benjamin: le chiffonnier ..., 785-786.

${ }^{25}$ Cfr. Marta Peirano y Sonia Bueno Gómez-Tejedor, El rival de Prometeo: vidas de autómatas ilustres.

${ }^{26}$ Cfr. Marta Peirano y Sonia Bueno Gómez-Tejedor, El rival de Prometeo..., 47. Los otros autómatas eran: der Zeichener (dibujante) y die Organistin (Organillera). 
Muchos de estos autómatas fueron construidos por interés científico, pues los estudios sobre la anatomía de los cuerpos buscaban replicar las funciones de los seres vivos, como la circulación sanguínea o los procesos respiratorios..$^{27}$ En 1748, el filósofo y físico Julien Offray de la Mettrie, en su tratado L'Homme Machine, imagina a Dios como un relojero y al cuerpo humano como un inmenso y complejo mecanismo de relojería. ${ }^{28}$ Para los científicos y filósofos de la época de las luces, la naturaleza era algo racional, y por tanto susceptible de ser explorada, conocida y replicada, ideas razonables y revolucionarias para la época.

Sin embargo, con el autómata jugador de ajedrez no se desentraña misterio alguno sobre el funcionamiento del cuerpo humano, sino que se creó uno nuevo en torno a la posibilidad de emular la capacidad humana de pensar. El turco parecía no tener comparación con los otros mecanismos de aquella época, pues mientras éstos podían ejecutar movimientos más o menos naturales, pero siempre limitados, el autómata con un diseño hasta grotesco y de movimientos lentos y torpes, "jugaba al ajedrez de un modo tan magistral que no había rival que se le resistiese" (Peirano y Bueno Gómez-Tejedor, El rival de Prometeo, 69).

Frente al autómata había una mesa amplia, con un tablero de ajedrez encima, y dos puertas al frente, que eran abiertas antes de cada partida para mostrar el mecanismo y convencer al público que en verdad funcionaba por sí mismo. La fama del autómata fue creciendo a lo largo de poco más de ochenta años, además de enfrentar a los mejores ajedrecistas de la época, se dice que venció a Federico el Grande de Prusia - lo cual parece ser un mito-, a Benjamin Franklin y al mismísimo Napoleón Bonaparte, aunque este último parece que no supuso ningún reto, pues el gran estratega bélico se distinguía por ser un pésimo jugador de ajedrez. ${ }^{29}$ Junto con la fama del autómata, también crecieron las sospechas sobre su verdadero funcionamiento; se hablaba de que estaba poseído diabólicamente; que en el interior había en realidad un enano experto jugador de ajedrez o que un niño prodigio en el juego era el que lo controlaba. Fueron varios los que escribieron con la intención de

${ }^{27}$ Cfr. Marta Peirano y Sonia Bueno Gómez-Tejedor, El rival de Prometeo ..., 47.

${ }^{28}$ Cfr. Julien Offray de La Mettrie, El hombre máquina.

${ }^{29}$ Cfr. Peirano y Bueno Gómez-Tejedor, El rival de Prometeo..., 123-126. 
desentrañar el misterio del autómata, aunque para muchos intérpretes de Benjamin, es un ensayo de Edgar Allan Poe, titulado El jugador de ajedrez de Mäzel, ${ }^{30}$ el que inspira la tesis I.

Poe vio al autómata en 1935, cuando se presentó en Richmond, en Estados Unidos, y un año después publicó su ensayo. En él, escribe que hay gente de gran agudeza intelectual, que no duda en afirmar que el autómata de Mäzel es realmente una máquina, que se mueve sin ninguna intervención humana y que por lo mismo, es el "invento más asombroso de la humanidad". ${ }^{31}$ Poe sospecha con agudeza de esta opinión del entendimiento común, pues aún los autómatas más sofisticados realizan movimientos siempre limitados, en cambio, en el juego de ajedrez no es posible realizar movimientos predeterminados, de manera que a un movimiento le siga necesariamente otro. En el juego de ajedrez, cuando se mueve una pieza, lo único seguro es la incertidumbre del siguiente movimiento. Así, aunque los movimientos del autómata estuvieran predeterminados, estarían siendo constantemente interrumpidos por los deseos indeterminados de su antagonista. Para Poe no hay analogía posible entre una y otra de las máquinas, y concluye que "es evidente que las acciones del autómata están dirigidas por una mente humana, y por ninguna otra cosa". ${ }^{32}$ Hay que señalar además que Poe niega que sea un enano el que controla al autómata, en cambio, Benjamin lo afirma, devolviéndole, como bien observa Roger Bartra, su carácter enigmático. ${ }^{33}$

Aunque quizá Benjamin haya conocido el ensayo de Poe, sus intenciones al citar esa imagen del pasado parecen ser otras. Tal vez su secre-

${ }^{30}$ Cfr. Edgar Allan Poe, Ensayos y críticas.

${ }^{31}$ Poe cita las Cartas sobre magia natural de Brewster, que ofrece un resumen de los autómatas más notables de la época, como la Carroza del señor Camus que inventó para entretenimiento del rey Luis XIV cuando era niño. O el mago de Maillardet, que era capaz de responder unas cincuenta preguntas durante el lapso de una hora. También escribe sobre la máquina calculadora del señor Babbage, que era capaz de realizar cálculos astronómicos y marítimos, e incluso ofrecerlos con tal certeza matemática que era capaz de corregir sus errores, y al final imprimía la información sin intervención alguna del ser humano.

${ }^{32}$ Cfr. Edgar Allan Poe, Ensayos y críticas.

${ }^{33} \mathrm{Cfr}$. Roger Bartra, El duelo de los Ángeles: locura sublime, tedio y melancolía en el pensamiento moderno. 
to se revela en el mismo método benjaminiano de pensar lo histórico a partir de imágenes. En el pasado, según Andre Monglond, se han conformado imágenes que han sido fijadas como por una placa fotosensible, y sólo el futuro tendrá reveladores lo suficientemente poderosos que hagan posible observar la imagen en todos sus detalles. Así, "ciertas páginas de Marivaux o de Rousseau dejan ver un sentido secreto que los lectores de su época no pudieron descifrar completamente". ${ }^{34}$ Se trata entonces de descifrar el sentido secreto de esas imágenes del pasado, pero no para afirmar su ilusoria existencia en el presente, sino para señalar la crisis de la actualidad.

Para Benjamin, la imagen del pasado surge de la remembranza involuntaria, que se enfoca súbitamente en el sujeto histórico y relampaguea en un instante de peligro. ${ }^{35}$ Ese recuerdo involuntario aparece no como un transcurso, sino como una imagen, que amenaza con desaparecer con cada presente que no se reconozca aludido en ella. Pero mientras el historiador historicista levanta una imagen "eterna" del pasado, el historiador materialista en cambio la atrapa tal y como esta se le enfoca en el momento del peligro, la mantiene en su singularidad y establece una experiencia única con ella. El peligro que advierte Benjamin, no sólo es la amenaza del fascismo, sino el de prestarse como instrumento de la clase dominante, la empatía (Einfühlung) del historiador historicista, cuyo origen es la apatía del corazón (Trägheit des Herzens), que "siempre resulta favorable al dominador del momento" (Benjamin, $\mathrm{Te}$ sis sobre la historia..., 21).

La capacidad del historiador materialista para aprehender la imagen del pasado depende de la agudeza de su consciencia sobre la crisis en que se encuentra el sujeto histórico, que de ninguna manera es un sujeto trascendental, sino la clase oprimida que lucha en ese momento de peligro y construye el espacio de la acción política: en la organización del pesimismo se descubre esa imagen del pasado, que no es posible

\footnotetext{
${ }^{34}$ Citado en Walter Benjamin, Tesis sobre la historia y otros fragmentos.

${ }^{35}$ Benjamin, Tesis sobre la historia y otros fragmentos. Las ideas que a continuación se expresan fueron tomadas de diversos pasajes de las tesis de Benjamin. Se sigue la traducción de Bolívar Echeverría, que además de incluir las notas, apuntes y variantes, es la que mejor traslada de la lengua alemana a la castellana el sentido de las ideas expresadas por el filósofo.
} 
abarcar contemplativamente. La imagen auténtica es fugaz, su verdad es siempre pasajera y corre el riesgo de que el más ligero soplo del progreso la haga desaparecer. La "apariencia" de la imagen "en cambio espera en su sitio, pues se aviene mejor con la eternidad" (Benjamin, Tesis sobre la historia..., 58).

El conocimiento histórico no es el de un momento eterno, sino de un instante. Al replegarse el pasado en un instante surge una imagen dialéctica como un "relámpago que va sobre todo el horizonte del pasado" y "destella en medio de una constelación de peligros" (39). En la imagen, el pasado y el presente se juntan para conformar una constelación, en la que la relación del pasado con el presente es dialéctica. "Articular históricamente algo pasado significa: reconocer en el pasado aquello que se conjunta en la constelación de uno y un mismo instante". Y en este procedimiento es que la imagen dialéctica hace saltar el continuum histórico.

Como es posible observar, el uso de imágenes en Benjamin es más que un mero recurso estilístico o metafórico, la alusión a imágenes del pasado y la conformación de imágenes dialécticas son una forma de concebir y construir críticamente el conocimiento histórico, rompiendo con la empatía del historiador historicista con la historia de los vencedores. De allí que la significación más profunda de sus imágenes dialécticas sea su momento crítico, destructivo, mediante el que se fomenta el despertar de los sueños de la modernidad.

La imagen del autómata jugador de ajedrez, por tanto, que oculta bajo la mesa a la teología en los salones de la filosofía, adquiere una significación crítica central que se expresa a lo largo de las tesis Sobre el concepto de historia. Desde esta perspectiva, una aproximación a las tesis nos permiten ubicar tres temáticas principales: la renovación crítica del materialismo histórico, a partir de la paradójica y provocadora aproximación a algunas ideas del mesianismo judío y el utopismo; la crítica al historicismo positivista y su concepto de progreso, que aún pervive en ciertas concepciones teóricas del "materialismo histórico", y la crítica del marxismo vulgar, en particular de la socialdemocracia y del marxismo bolchevique, y sus concepciones de trabajo y política. ${ }^{36}$

${ }^{36}$ Cfr. Echeverría, "Mesianismo y utopía", en Valor de uso y utopía. Este trabajo es deudor del análisis crítico de los ensayos de Bolívar Echeverría dedicados a Walter 
Por tanto, la tentativa benjaminiana consiste más que en una fusión de motivos dispares, o la afirmación de alguno de ellos, marxismo o mesianismo, en una puesta en juego, una puesta en tensión del discurso filosófico, del materialismo histórico y de la teología judía, para la renovación del carácter crítico del discurso y la práctica política de la izquierda. He allí el legado y la actualidad de este pensador excepcional.

\section{REFERENCIAS}

ADorno, Theodor y Walter Benjamin, Correspondencia: 1928-1940, Madrid, Trotta, 1998.

Arendt, Hannah, Hombres en tiempos de oscuridad, trad. Claudia Ferrari, Barcelona, Gedisa, 2001.

BARTRA, Roger, El duelo de los ángeles: locura sublime, tedio y melancolía en el pensamiento moderno, Bogotá, Fondo de Cultura Económica, 2004.

Benjamin, Walter, Dirección única, Madrid, Alfaguara, 1987.

Benjamin, Walter, Gesammelte Schriften, Frankfurt am Main, Suhrkamp, 1991. Benjamin, Walter, Tesis sobre la historia y otros fragmentos, trad. Bolívar Echeverría, México, Clío, 2005.

Benjamin, Walter, Über den Begriff Der Geschichte, Berlin, Suhrkamp, 2010.

BIRLE, Peter, y Friedhelm Schmidt-Welle (eds.), Wechselseitige Perzeptionen: Deutschland-Lateinamerika im 20. Jahrhundert, Frankfurt am Main, Vervuert, 2007.

ECHEVerría, Bolívar, Valor de uso y utopía, México, Siglo XXI, 1998.

FitTko, Lisa, Mi travesía de los Pirineos: evocaciones 1940-1941, Barcelona, Muchnik, 1988.

Hobsbawm, Eric, Historia del siglo xx, Buenos Aires, Crítica, 1998.

Löwy, Michael, Redención y utopía: el judaísmo libertario en Europa central: un estudio de afinidad electiva, Buenos Aires, Cielo por Asalto, 1997.

Löwy, Michael, Walter Benjamin: aviso de incendio. Una lectura de las tesis "sobre el concepto de la historia", Buenos Aires, Fondo de Cultura Económica, 2005.

La Mettrie, Julien Offray de, El hombre máquina, Buenos Aires, Eudeba, 1962.

PALMier, Jean Michel, Walter Benjamin: le chiffonnier, l'ange et le petit bossu: esthétique et politique chez Walter Benjamin, Paris, Klincksieck, 2006.

Benjamin, sin duda de los mejores ensayos que se han escrito sobre el tema en lengua española. 
Peirano, Marta, y Sonia Bueno Gómez-Tejedor, El rival de Prometeo: vidas de autómatas ilustres, Madrid, Impedimenta, 2009.

PoE, Edgar Allan, Ensayos y críticas, Madrid, Alianza Editorial, 1973.

Wohlfarth, Irving, Hombres del extranjero: Walter Benjamin y el parnaso judeoalemán, trad. Esther Cohen y Patricia Villaseñor, México, Taurus, 1999. 